\title{
Fertility control in wild mice after feeding with RU486 or methyl testosterone
}

\author{
Y. Gao and R. V. Short \\ Department of Physiology, Monash University, Melbourne, Victoria 3168, Australia
}

\begin{abstract}
Paraffin blocks containing either no steroid, $150 \mathrm{mg}$ RU486 $\mathrm{kg}^{-1}, 500 \mathrm{mg}$ methyl testosterone $\mathrm{kg}^{-1}$ or $1500 \mathrm{mg}$ methyl testosterone $\mathrm{kg}^{-1}$ were fed to wild mice (Mus musculus) in addition to the standard laboratory diet in four large ( $3 \mathrm{~m} \times 3 \mathrm{~m}$ ) outdoor pens for six months over the summer. The RU486 bait was provided for only 3 days every 18 or 21 days, whereas the methyl testosterone bait was available continuously. From a foundation stock of 20 mice (nine male, eleven female) in each pen, the population had increased to 253 (control), 72 (RU486), 249 (low methyl testosterone concentration) and 103 (high methyl testosterone concentration) at the end of six months, when $17 \%, 4 \%, 32 \%$ and $13 \%$ of the mature females were pregnant in the respective treatment groups. There was little evidence of an increase in the incidence of injuries in the androgen-treated animals. Daily estimation of water consumption in the pens proved to be a good non-invasive way of monitoring population growth during the course of the experiment. Intermittent feeding with a low concentration of RU486 appeared to be much more successful in inhibiting reproduction than continuous feeding with a high concentration of methyl testosterone, and it therefore offers a new method for controlling feral mouse populations.
\end{abstract}

\section{Introduction}

We have been investigating ways in which the oral administration of steroid hormones might be used to control rat and mouse populations (Gao and Short, 1993a, b, 1994). Of the four classes of steroid tested, a synthetic oestrogen (ethinyl oestradiol) proved to be ineffective because of its low palatability. A synthetic androgen (methyl testosterone), although having low palatability, could inhibit ovulation in laboratory rats and mice, and in addition induced major behavioural changes in female mice, with a marked increase in aggression; this could be of significant benefit in mouse control operations if it led to an increase in mortality. A synthetic gestagen (ORG 5933) was completely palatable, and very effective in inhibiting ovulation and parturition in rats and mice. Unfortunately, this compound was not available for further studies. The most promising steroid was the antigestagen RU486. In contrast to the androgen or gestagen, which have to be taken continuously to produce their antifertility effect, RU486 only needs to be administered intermittently, at an interval determined by the duration of gestation of the species in question. We have shown that if mice are given RU486 for 3 days every 21 days in free choice feeding trials, some live births still occur, but if the treatment interval is reduced to 18 days, all reproduction is halted (Gao and Short, 1994).

The purpose of the present experiment was therefore to compare the effectiveness of two concentrations of methyl

Revised manuscript received 7 February 1994. testosterone continuously available in paraffin wax blocks, or the intermittent administration of RU486 in paraffin wax blocks, for controlling the fertility of wild mice (Mus musculus) housed in outdoor enclosures with continuous access to alternative sources of food.

\section{Materials and Methods}

Paraffin wax blocks were prepared as described by Gao and Short (1993b, 1994). RU486 (Roussel-Uclaf, Paris) or methyl testosterone (Akzo, Oss) was added to the melted paraffin, followed by a mixture of blended cereals to give a ratio of $26 \%$ paraffin:74\% cereals. Blue dye (Queen Fine Foods Pty Ltd, Queensland) was added so that if necessary the bait could be detected in the gastrointestinal tract at autopsy, thus providing proof of ingestion. The paraffin mixture was poured into plastic dishes $7 \mathrm{~cm}$ square and $1 \mathrm{~cm}$ deep and allowed to set, to give individual paraffin blocks weighing approximately $40 \mathrm{~g}$. The blocks contained either $150 \mathrm{mg}$ RU $486 \mathrm{~kg}^{-1}, 500 \mathrm{mg}$ methyl testosterone $\mathrm{kg}^{-1}$ or $1500 \mathrm{mg}$ methyl testosterone $\mathrm{kg}^{-1}$. Control paraffin blocks were prepared in the same way but without addition of steroid.

Four outdoor pens, each $3 \mathrm{~m} \times 3 \mathrm{~m}$, were built in the Jock Marshall Reserve on the Clayton campus of Monash University. The pens were roofed and netted to make them rain and predator proof. The walls of the pens were made of $90 \mathrm{~cm}$ high metal sheets. The floor of each pen was concrete covered with sawdust bedding, and three bales (each $90 \mathrm{~cm} \times$ $40 \mathrm{~cm} \times 40 \mathrm{~cm}$ ) of fresh meadow hay were placed in each pen 
Table 1. Number of mice at the beginning and end of 6 months treatment

\begin{tabular}{|c|c|c|c|c|c|c|c|c|c|}
\hline \multirow{2}{*}{$\begin{array}{l}\text { Treatment group } \\
\text { Control }\end{array}$} & \multicolumn{2}{|c|}{$\begin{array}{l}\text { Number at } \\
\text { beginning of expt }\end{array}$} & \multicolumn{2}{|c|}{$\begin{array}{l}\text { Number of } \\
\text { foundation mice } \\
\text { at end of expt }\end{array}$} & \multicolumn{2}{|c|}{$\begin{array}{l}\text { Number of } \\
\text { additional juveniles } \\
\text { and adults at } \\
\text { end of expt }\end{array}$} & \multirow{2}{*}{$\begin{array}{l}\text { Number of } \\
\text { unsexed newborn } \\
(<5 \mathrm{~g}) \text { at end } \\
\text { of expt } \\
32\end{array}$} & \multirow{2}{*}{$\begin{array}{c}\text { Carcasses } \\
0\end{array}$} & \multirow{2}{*}{$\begin{array}{c}\text { Total number } \\
\text { at end of expt } \\
253\end{array}$} \\
\hline & 9 & 11 & 9 & 11 & 100 & 101 & & & \\
\hline $\begin{array}{l}\text { RU486 } \\
\qquad\left(150 \mathrm{mg} \mathrm{kg}^{-1} \text { block) }\right.\end{array}$ & 9 & 11 & 8 & 9 & 27 & 27 & 0 & $1^{a}$ & 72 \\
\hline $\begin{array}{l}\text { Methyl testosterone } \\
\text { (500 } \mathrm{mg} \mathrm{kg}^{-1} \text { block) }\end{array}$ & 9 & 11 & 8 & 10 & 96 & 88 & 42 & $5^{b}$ & 249 \\
\hline $\begin{array}{l}\text { Methyl testosterone } \\
\text { (1500 } \mathrm{mg} \mathrm{kg}^{-1} \text { block) }\end{array}$ & 9 & 11 & 6 & 8 & 43 & 23 & 20 & $3^{a}$ & 103 \\
\hline
\end{tabular}

${ }^{\mathrm{a}}$ Adult; ${ }^{b}$ newborn.

for shelter and as an additional natural source of food. A dim red light was mounted on the ceiling of each pen for observation of the animals during the night. Water was supplied ad libitum from three drinking bottles mounted on the walls of each pen. Daily water consumption was recorded for 3 days every 18 or 21 days. A water bottle was mounted outside the pens to control for loss of water through evaporation.

Standard mouse laboratory diet (raw chow, G2 + : King and Co., North Melbourne), consisting of pellets of wheatmeal, soybean meal, linseed meal, rice pollard, meat meal, molasses, vitamins, minerals, calcium and phosphorus, was supplied ad libitum in several feeding bowls per pen. There were two baiting points per pen for the paraffin blocks, which were suspended from hooks mounted on the walls. The amount of block removed (amount ingested plus amount gnawed and wasted) was monitored for 3 days every 18 or 21 days by weighing. The androgen blocks were available throughout the 6 month treatment, whereas the antigestagen blocks were available for only 3 days every 18 or 21 days.

At the start of the experiment, RU486 blocks were provided for only 3 days every $2 I$ days. When it became apparent from simultaneous studies in laboratory mice that this dosage regimen still allowed some live births to occur (Gao and Short, 1994), the treatment interval was reduced to 18 days for the last five treatment periods in the study.

Wild mice were caught in the Mallee wheat growing area of Victoria. Nine adult males and 11 females were released into each of the four pens between 14 and 16 September 1992 (early Spring) after they were individually weighed and toe clipped to mark them as foundation stock. The pens were assigned randomly to control, antigestagen, or low or high androgen treatments. Treatment started on 16 September (day 0) when the appropriate paraffin blocks were put out in all of the pens.

The study was terminated between 9 and 12 March 1993. The hay bales in each pen were carefully taken apart by hand, and any carcasses recorded. All the live mice in each pen were caught and killed by placing them in a bin filled with carbon dioxide. They were then weighed, sexed and dissected to determine which females were pregnant. The surviving foundation animals were identified from their toe clips. Any injuries in the foundation animals were carefully recorded to assess the level of aggression, and their testes and ovaries were weighed.

Results are presented as means \pm SEM throughout. Comparisons between means of control and treatment groups were made using the GLM procedure in the SAS statistic package with the Regwf multiple-range procedure (SAS, 1985) for testicular weights, and using the Tukey's HSD multiple-range comparison in Systat (1990) for the consumption of paraffin blocks or water. Differences were considered not significant when $P>0.05$.

\section{Results}

The largest number of mice was present at the end of the experiment in the pen of the control group (253), closely followed by the low-dose methyl testosterone group (249), suggesting that at this concentration the steroid had little or no effect in inhibiting fertility (Table 1). The high-dose methyl testosterone group contained 103 mice, and the antigestagen group only 72 . These differences were evidently attributable to decreased fertility rather than to increased mortality, since few carcasses were found in any group, and most of the foundation animals were accounted for, although the highest number missing were in the high androgen group.

Confirmation of this antifertility effect could be seen in the number of newborn young present at the end of the experiment; there were none in the antigestagen group, compared with 32,42 and 20 in the control, low and high methyl testosterone groups, respectively (see Table 1 ). The number of pregnant females showed a similar trend, with only one in the antigestagen group, three in the high dose methyl testosterone group, and 21 in the low dose methyl testosterone group and II in the controls (see Table 2).

There was little evidence to suggest that the androgentreated mice were more aggressive, when judged by the number of scars on the body of the foundation animals at the end of experiment. However, the high androgen group did have the highest incidence of missing tails in the foundation females, and the largest number of foundation animals un- 
Table 2. Number of pregnant mice and litter size at the end of 6 months treatment

\begin{tabular}{lccc}
\hline Treatment group & $\begin{array}{c}\text { Number pregnant } \\
\text { (number of foundation } \\
\text { animals pregnant) }\end{array}$ & $\begin{array}{c}\text { Mature females } \\
\text { pregnant (\%) }\end{array}$ & Litter size \\
\hline Control & $11(5)$ & 17 & $7.1 \pm 0.3$ \\
RU486 (150 $\mathrm{mg} \mathrm{kg}^{-1}$ block) & $1(1)$ & 4 & 9 \\
Methyl testosterone (500 $\mathrm{mg} \mathrm{kg}^{-1}$ block) & $21(4)$ & 32 & $5.9 \pm 0.3$ \\
Methyl testosterone (1500 $\mathrm{mg} \mathrm{kg}^{-1}$ block) & $3(2)$ & 13 & $6.7 \pm 1.3$ \\
\hline
\end{tabular}

Table 3. Injuries in foundation mice at the end of treatment

\begin{tabular}{|c|c|c|c|c|c|c|}
\hline Treatment group & $n$ & Scars/mouse & $\begin{array}{l}\text { mice } \\
\text { Number with } \\
\text { part of tail } \\
\text { missing }\end{array}$ & $n$ & Scars/mouse & $\begin{array}{l}\text { mice } \\
\text { Number with } \\
\text { part of tail } \\
\text { missing }\end{array}$ \\
\hline Control & 9 & $20.7 \pm 2.5$ & 0 & 11 & $11.7 \pm 2.3$ & 0 \\
\hline RU486 (150 $\mathrm{mg} \mathrm{kg}^{-1}$ block) & 8 & $17.1 \pm 3.5$ & 0 & 9 & $0.6 \pm 1.6$ & 1 \\
\hline Methyl testosterone (500 $\mathrm{mg} \mathrm{kg}^{-1}$ block) & 8 & $20.8 \pm 2.8$ & 2 & 10 & $11.9 \pm 2.4$ & 1 \\
\hline Methyl testosterone ( $1500 \mathrm{mg} \mathrm{kg}^{-1}$ block) & 6 & $20.8 \pm 4.5$ & 0 & 8 & $9.5 \pm 2.6$ & 5 \\
\hline
\end{tabular}

accounted for and presumed dead (see Table 3). There also appeared to be an overall deficiency of females in the high androgen group at the end of the experiment ( 43 males: 23 females); this significant skewing of the tertiary sex ratio was not seen in any other group (see Table 1), and could be attributable to increased female mortality as a result of aggression. Since aggression is likely to be density dependent, the number of animals present in each pen must be considered when interpreting these results. For example, the small number of injuries found in female mice in the antigestagen group could be attributable to the small number of animals in the pen.

Water consumption at the very end of the experiment (Fig. 1) gave a good indication of the numbers of mice present in the four enclosures at that time (see Table 1). Obviously water consumption will give only a rough indication of absolute population size, as it will vary with ambient temperature, activity level, bodyweight, and number of animals pregnant or lactating. Nevertheless, it is a useful non-invasive method for studying how the mouse population changes over time in the different treatment groups. It is clear that the control and low androgen treatment groups had entered a phase of exponential population growth during the last three months of the experiment; the rate of growth of the population of the high androgen treatment group was reduced significantly, an effect that was even more pronounced in the RU486-treated group.

The bodyweight of the foundation male mice increased to a similar extent in all groups during the course of the experiment (Table 4). Testicular weights were significantly lower in the two androgen-treated groups than in the controls; the effect was greatest in those mice receiving the higher concentration of androgen, although it is doubtful whether this $7 \%$ decrease would have been sufficient to depress male fertility significantly. The testes were not weighed in the RU486 group, as previous experiments had established that RU486 even when fed continuously for a month had no effect on testicular weight in mice (Gao and Short, 1994).

On the first two occasions when paraffin wax blocks were made available the numbers of mice in the four enclosures would have been very similar. The RU486-treated blocks were consumed at about the same rate as the control blocks (Fig. 2) confirming the high palatability of RU486-treated blocks found when tested in laboratory mice (Gao and Short, 1994). By contrast, the androgen-treated blocks were significantly less palatable, with the high concentration block being the more unpalatable. Again, this confirms the reduced palatability of androgen-treated blocks recorded in laboratory mice (Gao and Short, 1993b).

From days $43-45$ onwards, the daily consumption of the control blocks increased with respect to that of the RU486 blocks. This difference is almost certainly due to the much faster population growth of the control animals. The increasing consumption of the androgen-treated blocks also reflected the increasing population growth in these groups. The androgentreated blocks remained relatively unpalatable throughout the experiment. Unfortunately, there was no evidence to suggest that female fetuses or neonates in either of the androgentreated groups had been sterilized for the rest of their adult lives. This may be because pregnant and lactating female rodents can develop a specific aversion to androgen-containing baits (Gao and Short, 1993b). 


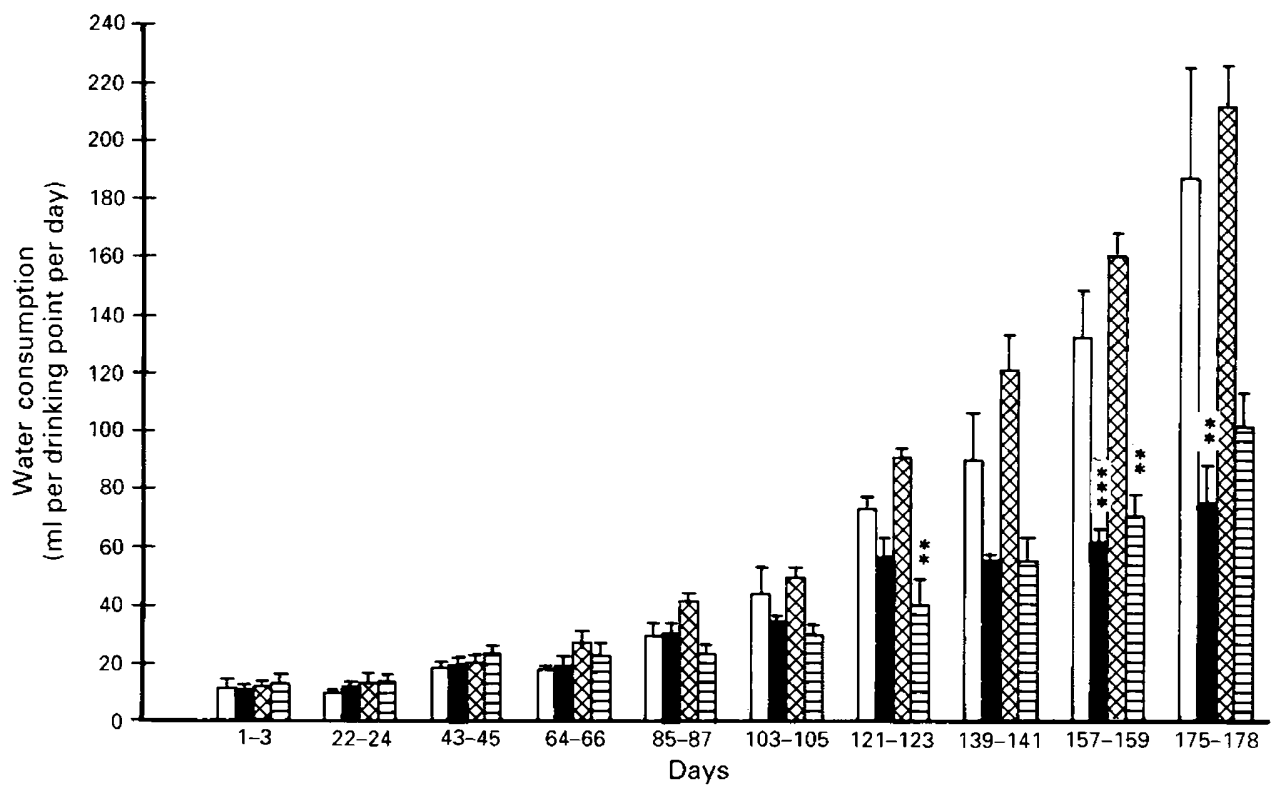

Fig. 1. Water consumption by wild mice in four enclosures. At the start of the experiment there were nine males and 11 females per enclosure. They were given $(\square)$ untreated paraffin blocks (control); ( $\square$ ) paraffin blocks containing $150 \mathrm{mg}$ RU486 $\mathrm{kg}^{-1}$ for 3 days every 18-21 days; ( $)$ paraffin blocks containing $500 \mathrm{mg}$ methyl testosterone $\mathrm{kg}^{-1}$; or (⿴) paraffin blocks containing $1500 \mathrm{mg}$ methyl testosterone $\mathrm{kg}^{-1}$. Water consumption from the three drinking bottles in each enclosure was recorded for 3 days every 18-21 days. Comparison with contemporary controls, $* * p<0.01, * * * P<0.001$.

Table 4. Bodyweight of foundation male mice before and after treatment and testicular weight

\begin{tabular}{llccc}
\hline Treatment group & $n$ & Before treatment & After treatment & $\begin{array}{c}\text { Paired testicular } \\
\text { mass (mg) }\end{array}$ \\
\hline Control & 9 & $16.7 \pm 1.0$ & $22.3 \pm 0.8$ & $147.1 \pm 10$ \\
RU486 (150 mg kg ${ }^{-1}$ block) & 8 & $17.7 \pm 0.9$ & $24.0 \pm 0.9$ & - \\
Methyl testosterone (500 mg kg ${ }^{-1}$ block) & 8 & $16.2 \pm 0.9$ & $22.4 \pm 0.8$ & $113.5 \pm 6.6^{*}$ \\
Methyl testosterone (1500 $\mathrm{mg} \mathrm{kg}^{-1}$ block) & 6 & $16.9 \pm 0.9$ & $23.6 \pm 1.2$ & $108.2 \pm 9.5^{*}$ \\
\hline
\end{tabular}

${ }^{*} P<0.05$. Bodyweight was used as a covariate.

By recording the bodyweight of all the mice in the four treatment groups at the end of the experiment, it was possible to calculate that the total consumption of steroid in the RU486, low methyl testosterone and high methyl testosterone groups was $10.8,14.6$ and $26.4 \mathrm{mg} \mathrm{kg}^{-1}$ bodyweight day ${ }^{-1}$, respectively. Consumption is used to describe the amount of the block that was removed; it was not all swallowed by the mice, since small pieces were discarded beneath the blocks, particularly those that contained the higher concentration of methyl testosterone. We do not know how much steroid was absorbed from the paraffin wax that was actually ingested.

\section{Discussion}

Over the last three decades there have been many studies on potential use of chemosterilants for rodent control (Davis, 1961; Marsh and Howard, 1973; Marsh, 1988). Theoretical modelling of rodent population growth has shown that much better control is achieved by sterilizing a proportion of the population than by killing a similar proportion (Knippling and McGuire, 1972). However, no satisfactory chemosterilants have hitherto been developed for rodents (Gao and Short, 1993a). The results of this study demonstrate that the intermittent provision of paraffin wax blocks containing RU486 to wild mice living in outdoor enclosures with abundant alternative food sources is a very effective way of controlling their rate of population growth. This appears to be more effective than the continuous availability of paraffin wax blocks containing methyl testosterone, since such baits are relatively unpalatable to mice at the steroid concentrations necessary to inhibit reproduction.

In contrast to studies of laboratory mice in a confined environment, where androgen treatment markedly increased the aggression of males towards females (Gao and Short, 


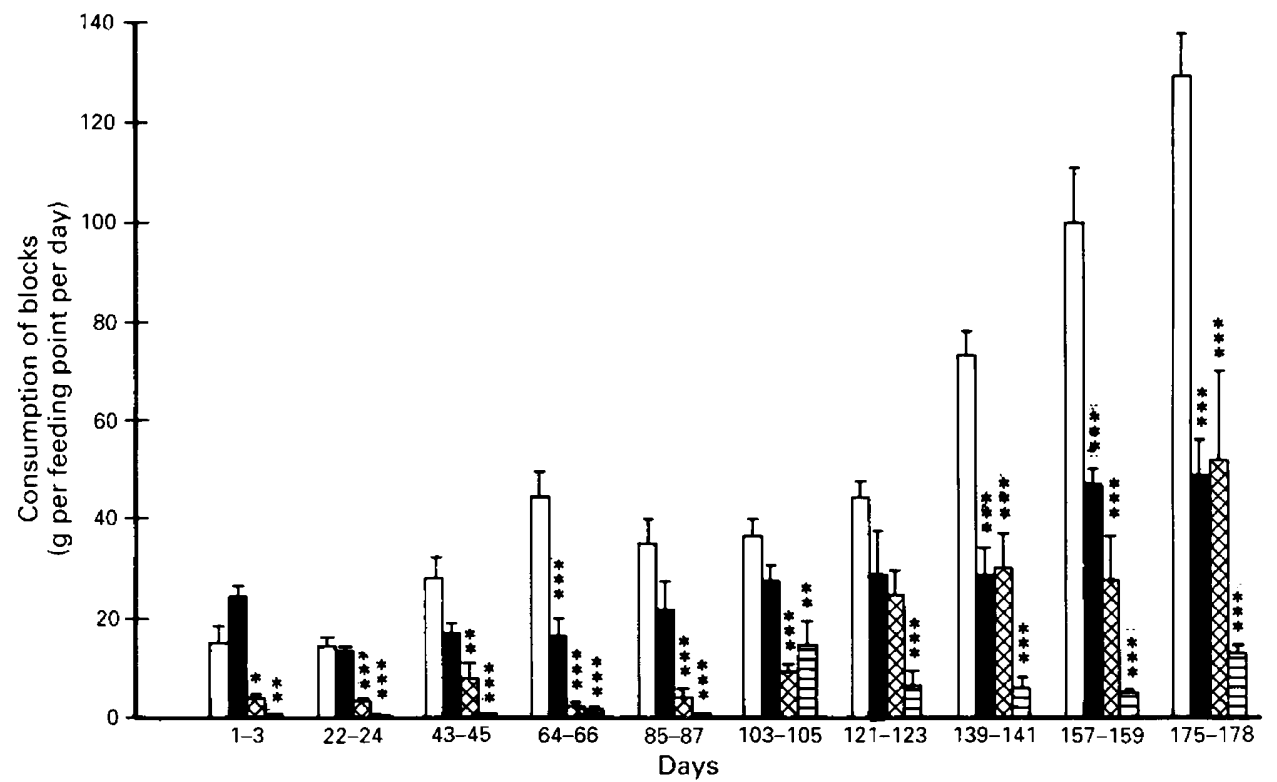

Fig. 2. Consumption of paraffin blocks by wild mice in four enclosures. At the start of the experiment there were nine males and 11 females per enclosure. They were given ( $\square$ ) untreated paraffin blocks (controls); ( $\square$ ) paraffin blocks containing $150 \mathrm{mg} R \mathrm{RU}_{486} \mathrm{~kg}^{-1}$ for 3 days every $18-21$ days; $(\otimes)$ paraffin blocks containing $500 \mathrm{mg}$ methyl testosterone $\mathrm{kg}^{-1}$; or (目) paraffin blocks containing $1500 \mathrm{mg}$ methyl testosterone $\mathrm{kg}^{-1}$. Each enclosure had two feeding points for the paraffin wax blocks; consumption of blocks was recorded for 3 days every $18-21$ days. Comparison with contemporary controls, ${ }^{*} P<0.05,{ }^{* *} P<0.01,{ }^{* * *} P<0.001$.

1993b), there was little evidence of increased aggression in these androgenized wild mice housed in large outdoor enclosures with abundant hay for nesting material and shelter. There was no significant increase in the number of scars on the body in androgen treated versus control males or females. However, at the end of the experiment, the highest number of foundation females with parts of their tails missing, the most skewed sex ratio, and the highest number of foundation males and females that were unaccounted for and presumed dead were in the high androgen treatment group.

One of the problems with population studies of mice is how to assess the number of animals present at any one time. The difficulty with selective trapping is that it may interfere with the study population; if lactating females are caught, their young may die or be killed in the nest before they are released. Trap shyness may also develop if animals have to be caught repeatedly. We have found that the simple procedure of measuring water consumption appeared to provide a useful indication of the size of the population, and correlated well with a count of the number of animals present in each of the four enclosures at the end of the experiment.

We have previously described how fertility control, particularly when used after a conventional poisoning campaign, or following a seasonal decline in numbers over the winter, may prove to be a valuable and effective strategy for controlling feral rodent populations in the wild (Gao and Short, 1993a). Of the steroids we tested, the antigestagen RU486 in paraffin wax blocks seems to be the most effective in inhibiting reproduction in the laboratory, and this study demonstrates its potential usefulness in wild mice in a more natural environment. Its great advantages are that it is highly palatable to rats and mice, can be administered intermittently, and shows a degree of species specificity, as it is without effect for example in horses, cats, chickens and some marsupials (Gao and Short, 1993b). Whether antigestagens will ever be used for rodent control in the field will depend on their cost and availability.

The authors thank the Grains Research and Development Corporation of Australia for partial financial support, A. Ulmann, Roussel-Uclaf for donating the RU486, the Department of Ecology and Evolutionary Biology, Monash University for allowing us to construct mouse enclosures in the Jock Marshall Reserve, F. X. Jiang, A. Turner and M. Cowley for their assistance in catching and dissecting all the mice at the end of the experiment, and to D. Finkelstein and G. Shaw for assistance in statistical analysis.

\section{References}

Davis DE (1961) Principles for population control by gametocides Transactions of the North American Wildlife and Natural Resources Conference 26 160-170

Gao Y and Short RV (1993a) The control of rodent populations Oxford Reviews of Reproductive Biology 15 265-310

Gao Y and Short RV (1993b) Use of an oestrogen, androgen or gestagen as a potential chemosterilant for control of rat and mouse populations Journal of Reproduction and Fertility 97 39-49

Gao $Y$ and Short RV (1994) Fertility control in laboratory rats and mice after feeding with the antigestagen RU486 Journal of Reproduction and Fertility 101 477-481

Knippling EF and McGuire JU (1972) Potential role of sterilisation for suppressing rat populations. A theoretical appraisal. Technical Bulletin No. 1455 PP I-27. US Department of Agriculture, Agricultural Research Service, Maryland

Marsh RE (1988) Chemosterilants for rodent control. In Rodent Pest Management Pp 353-367 Ed. I Prakash, CRC Press, Florida

Marsh RE and Howard WE (1973) Prospects of chemosterilant and genetic control of rodents Bulletin of the World Health Organization 48 309-316

SAS (1985) SAS/STAT Guide for Personal Computers Version 6. SAS Institute, Cary, NC

Systat (1990) The System for Statistics Systat Inc., Evanston, IL 